\title{
Impact of land use change on greenhouse gases emissions in peatland: a review
}

\author{
Ryusuke Hatano \\ Research Faculty of Agriculture, Hokkaido University, Kita 9, Nishi 9, Kita-ku, Sapporo 060-8589, Japan \\ Received September 10, 2018; accepted December 22, 2018
}

\begin{abstract}
Peatland is a significant storage of carbon and nitrogen on the earth's surface. This paper reviews the impacts of changes in water table level and mineral nitrogen associated with human activities on greenhouse gases emissions in tropical peatland and northern boreal and temperate peatland, and evaluates the optimal water table level to minimize greenhouse gases emissions. $\mathrm{CH}_{4}$ emission increased significantly with the rise of ground water table level above $-20 \mathrm{~cm}$, and larger in northern peatland with plant mediated $\mathrm{CH}_{4}$ emission than tropical peatland with plant mediated oxygen supply. However, forest disturbance by fire in tropical peatland increased $\mathrm{CH}_{4}$ flux to the similar level

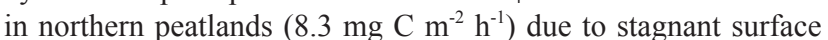
water associated with the peat subsidence. On the other hand, $\mathrm{CO}_{2}$ and $\mathrm{N}_{2} \mathrm{O}$ emissions were significantly lager in tropical peatland than in northern peatland especially due to nitrogen fertilization. $\mathrm{CO}_{2}$ and $\mathrm{N}_{2} \mathrm{O}$ emissions increased with falling ground water table level below -40 to $-80 \mathrm{~cm}\left(19 \mathrm{Mg} \mathrm{Cha}^{-1} \mathrm{y}^{-1}\right.$ for $\mathrm{CO}_{2}$ and $700 \mathrm{~kg} \mathrm{~N}$ $\mathrm{ha}^{-1} \mathrm{y}^{-1}$ for $\mathrm{N}_{2} \mathrm{O}$ ). Total global warming potential was significantly low in the ground water table level from -20 and $-40 \mathrm{~cm}$.

Keywords: carbon dioxide, ground water table, methane, nitrogen fertilizer, nitrous oxide, peatland
\end{abstract}

\section{INTRODUCTION}

Peatland is generated in wetland due to lower microbial decomposition than plant production. It has been developed at the organic matter accumulation rate of 100 to $200 \mathrm{~kg}$ $\mathrm{C} \mathrm{ha}^{-1} \mathrm{y}^{-1}$ for past 10000 years, and the area is 4.4 million $\mathrm{km}^{2}, 4$ million $\mathrm{km}^{2}$ in northern boreal and temperate region and 0.4 million $\mathrm{km}^{2}$ in tropical region (Yu et al., 2010). Although the area occupies only $3 \%$ of terrestrial area, it contains 612 Gt C (562 Gt C in northern boreal and temperate peatland, $50 \mathrm{Gt} \mathrm{C}$ in tropical peatland), accounting for $25 \%$ of total soil carbon. However, peatland is different

\footnotetext{
*Corresponding author e-mail: hatano@chem.agr.hokudai.ac.jp
}

among regions. Northern boreal and temperate peatland is usually covered by small vegetation, sphagnum (bog) and carex and shrub (fen). On the other hand, tropical peatland is covered by trees (peat swamp forest). Northern boreal and temperate peat profile is composed of fine fibric vegetation materials, it makes fine pore system. On the other hand, tropical peat profile contains woody materials, it makes macropore system. Therefore, natural tropical peatland has high water permeability (Melling, 2016).

As peatland is composed of organic matter, peat decomposition produces a significant amount of greenhouse gases (GHGs); carbon dioxide $\left(\mathrm{CO}_{2}\right)$ aerobically, methane $\left(\mathrm{CH}_{4}\right)$ anaerobically and nitrous oxide $\left(\mathrm{N}_{2} \mathrm{O}\right)$ both aerobically and anaerobically. Global warming potential (GWP) of $\mathrm{CH}_{4}$ and $\mathrm{N}_{2} \mathrm{O}$ is 28 and 265 times larger than $\mathrm{CO}_{2}$, respectively, over a 100-year period, and those GWP values do not include climate-carbon feedbacks (IPCC, 2014), and $\mathrm{N}_{2} \mathrm{O}$ is an important ozone-depleting substance emitted into the atmosphere (UNEP, 2013). Land use change due to disturbance of peatland by fire and clearance of vegetation and the development of peatland for agricultural land use by drainage, plowing and fertilization influence GHGs emissions (Page and Baird, 2016; van der Werf et al., 2009). Falling ground water level increases $\mathrm{CO}_{2}$ (Couwenberg et al., 2010; Ishikura et al., 2017, 2018), but decreases $\mathrm{CH}_{4}$ emission (Couwenberg et al., 2010; Ishikura et al., 2018). $\mathrm{CO}_{2}$ emission increases with the increase of temperature (Lloyd and Taylor, 1994). On the other hand, $\mathrm{CH}_{4}$ emission is controlled by redox potential in soil (Takai, 1970). Therefore, $\mathrm{CH}_{4}$ emission is influenced by the ground water level of peatland, the water permeability of peat soil. Lower 
permeable peat with finer pore system may produce higher $\mathrm{CH}_{4}$ emission. Concerning $\mathrm{N}_{2} \mathrm{O}$ emission, it increases with increase of organic matter decomposition and nitrogen fertilization application (Mu et al., 2009). Although it is not clearly mentioned the relationship between $\mathrm{N}_{2} \mathrm{O}$ emission and ground water table level, nitrogen mineralization with falling ground water level may increase $\mathrm{N}_{2} \mathrm{O}$ emission. However, nitrogen fertilizer application inhibits microbial organic matter decomposition, although it stimulates plant root respiration (Zhou et al., 2014).

These mentioned above suggest that $\mathrm{CH}_{4}$, and $\mathrm{N}_{2} \mathrm{O}$ emissions together with $\mathrm{CO}_{2}$ emissions can be controlled by the ground water table level. The aim of this paper is to discuss about optimal ground water table level minimizing $\mathrm{CO}_{2}, \mathrm{~N}_{2} \mathrm{O}$ and $\mathrm{CH}_{4}$ emissions by reviewing the published papers.

Wetland is a major source of $\mathrm{CH}_{4}$. Natural wetland emits $217 \mathrm{Tg} \mathrm{CH}_{4} \mathrm{y}^{-1}$, accounting for $63 \%$ of total natural $\mathrm{CH}_{4}$ emission, and rice paddy field emits $36 \mathrm{Tg}^{\mathrm{C}} \mathrm{CH}_{4} \mathrm{y}^{-1}$ accounting for $11 \%$ of total anthropogenic $\mathrm{CH}_{4}$ emission (IPCC, 2013). $\mathrm{CH}_{4}$ is produced in reductive subsoil, transported to top soil by molecular diffusion or ebullition as gas bubbles, and emitted from the surface of the soil or the plant leaves through aerenchyma from the roots (Schütz et al., 1989), but $90 \%$ of the $\mathrm{CH}_{4}$ produced in soil is oxidized during the transportation in the rhizosphere, either by oxygen released from plant roots or by other electron acceptors such as $\mathrm{Fe}$ (III) and $\mathrm{SO}_{4}{ }^{2-}$ (Kolb and Horn, 2012) . Ground water table level is major controlling factor of $\mathrm{CH}_{4}$ emission (Couwenberg et al., 2010; Ishikura et al., 2018). $\mathrm{CH}_{4}$ emission increases significantly when ground water table level rise above $-20 \mathrm{~cm}$, however, $\mathrm{CH}_{4}$ emission was lower in tropical peatland than in northern boreal and temperate peatland (Couwenberg et al., 2010) (Fig. 1). This is probably due to rapid fluctuation of ground water table level associated with better water permeability in tropical peatland (Takahashi, 1999). $\mathrm{CH}_{4}$ is produced in anaerobic condition by methanogenic bacteria using acetate and $\mathrm{CO}_{2}+\mathrm{H}_{2}$ after the sequential utilization of a series of electron acceptors of oxygen, $\mathrm{NO}_{3}{ }^{-}, \mathrm{Mn}(\mathrm{IV}), \mathrm{Fe}(\mathrm{III})$, and $\mathrm{SO}_{4}{ }^{2-}$ (Takai, 1970). Therefore, peat soil with lower permeability, lower fertility and lower contamination of mineral soil produces $\mathrm{CH}_{4}$ more easily due to less contain of electron acceptors. Recent global model uses 0.2 to 0.25 for the $\mathrm{CH}_{4} / \mathrm{CO}_{2}$ mole ratio in boreal natural peatland and 0.0052 in tropical natural peatland (Spahni et al., 2011). This is because of strong oxidizing power in natural tropical peatland induced by the plant mediate oxygen supply through aerial roots (Adji et al., 2014) and fast water flow in well water permeable peat layer (Kelly et al., 2014). Peat fire or clear tree cutting increases $\mathrm{CH}_{4}$ emission in tropical peatland due to the disappearance of plant mediate oxygen supply and the rise of ground water table level with peat subsidence, while drainage decreases $\mathrm{CH}_{4}$ emission due to the fall of ground water table level (Adji et al., 2014; Jauhiainen et al., 2008)

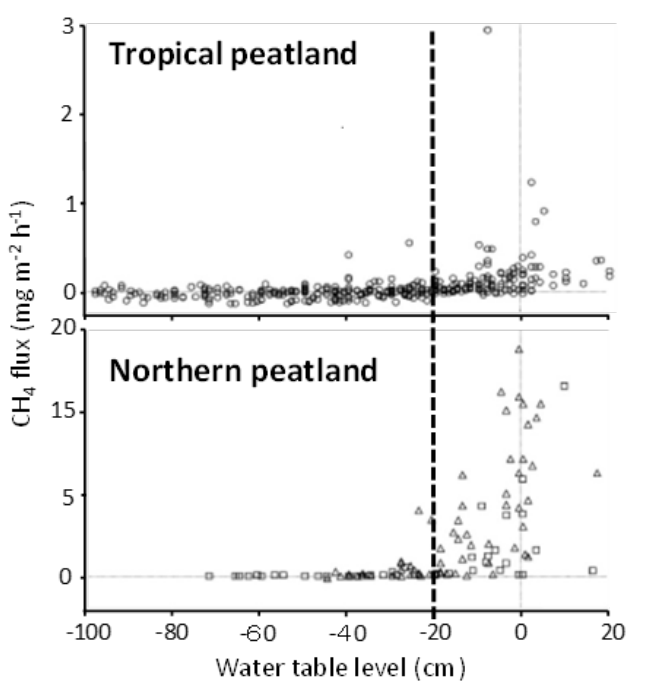

Fig. 1. Relationship between $\mathrm{CH}_{4}$ flux and ground water table level. Dashed line shows $-20 \mathrm{~cm}$ of ground water table level at which $\mathrm{CH}_{4}$ flux clearly increased (modified from Couwenberg et al., 2010).

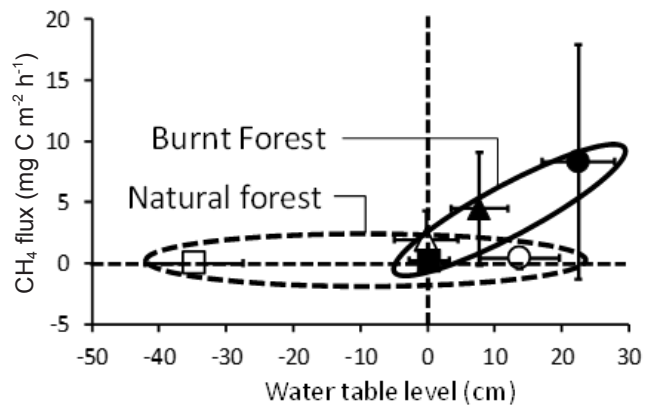

Fig. 2. Relationship between $\mathrm{CH}_{4}$ flux and ground water table level in a tropical peatland (modified from Adji et al., 2014).

(Fig. 2). Maximum $\mathrm{CH}_{4}$ flux was $8.3 \mathrm{mg} \mathrm{C} \mathrm{m}^{-2} \mathrm{~h}^{-1}$ in burnt area. This is significantly large value within tropical peatland other than rice paddy fields (2.6-11 (Hadi et al., 2005) and up to $26 \mathrm{mg} \mathrm{C} \mathrm{m}^{-2} \mathrm{~h}^{-1}$ (Furukawa et al., 2005)) and is similar to the maximum of $\mathrm{CH}_{4}$ emission in boreal and temperate peatland (Couwenberg et al., 2010).

$\mathrm{CH}_{4}$ flux from tree stem in natural tropical peatland is reported, but the value was only $0.021 \mathrm{mg} \mathrm{C} \mathrm{m}^{-2} \mathrm{~h}^{-1}$ (Pangala et al., 2013). On the other hand, in northern boreal and temperate peatlands, pond vegetation accelerates $\mathrm{CH}_{4}$ emission due to transportation through the aerenchyma. An observation in a thermokarst depression of 63.7 ha including pond, wet grassland, dry grassland near forest in Yakutia for four years from 2006 to 2009 showed that $96.3 \pm 5.4 \%$ of total $\mathrm{CH}_{4}$ emission was emitted from thermokarst pond (the area was $60.6 \pm 19.2 \%$ of the total area) and plant mediated $\mathrm{CH}_{4}$ emission from the pond vegetation accounted for $57.9 \pm$ $23.2 \%$ of total $\mathrm{CH}_{4}$ emission (Desyatkin et al., 2014).

Natural wetland is not a source of $\mathrm{N}_{2} \mathrm{O}$, rather a sink of $\mathrm{N}_{2} \mathrm{O}$. This is because of slow $\mathrm{N}$ mineralization, low nitrification activity, and high denitrification activity in 
the anaerobic condition (Kolb and Horn, 2012). But, once peatland is drained and agriculturally used, the peatland emits $\mathrm{N}_{2} \mathrm{O}$ significantly. Significantly large amount of $\mathrm{N}_{2} \mathrm{O}$ emission more than $200 \mathrm{~kg} \mathrm{~N}^{-1}$ was recorded in $\mathrm{NO}_{3}-\mathrm{N}$ accumulated upland fields in tropical peatland especially in wet season (Takakai et al., 2006; Toma et al., 2011) and 9 to $14 \mathrm{~kg} \mathrm{~N} \mathrm{ha}^{-1}$ was found even in tundra peatland (Repo et al., 2009). This is because of nitrogen application for crop production and incomplete denitrification with $\mathrm{NO}_{3}-\mathrm{N}$ leaching (Kolb and Horn, 2012). $\mathrm{N}_{2} \mathrm{O}$ emission from agricultural soil accounts for $34 \%$ of total anthropogenic $\mathrm{N}_{2} \mathrm{O}$ emission of 6.9 $\mathrm{Tg} \mathrm{N} \mathrm{y}^{-1}$, although $\mathrm{N}_{2} \mathrm{O}$ emission from natural ecosystem is estimated to be $11.0 \mathrm{TgN} \mathrm{y}^{-1}$ (IPCC, 2013). Denitrification is the major $\mathrm{N}_{2} \mathrm{O}$ production process in most soils, although $\mathrm{N}_{2} \mathrm{O}$ is produced in nitrification process (Šimek et al., 2002). Denitrification rate in soil is increased with the increases of $\mathrm{NO}_{3}{ }^{-}$content, available organic carbon content, temperature, soil moisture (Saggar et al., 2013), and decrease of soil pH (Mukumbuta et al., 2018). $\mathrm{N}_{2} \mathrm{O}$ is produced as an intermittent product through the process of $\mathrm{NO}_{3}^{-}$reduction to $\mathrm{N}_{2}$ by nitrate respiration of denitrifers. Therefore, presence of $\mathrm{NO}_{3}{ }^{-}$and available organic carbon is indispensable for $\mathrm{N}_{2} \mathrm{O}$ production in denitrification. $\mathrm{N}_{2} \mathrm{O}$ is mainly produced in the range of water-filled pore space (WFPS) between 60 to $100 \%$, because optimal WFPS for nitrification producing $\mathrm{NO}_{3}^{-}$is around 60 while $100 \%$ of WFPS (water saturation) is optimal for denitirification (Linn and Doran, 1984). Peat soil has high amount of pore space, and drained and plowed agricultural peat soil may have ideal WFPS for nitrification and denitrification processes. Soil $\mathrm{pH}$ is also important for denitrification. The $\mathrm{N}_{2} \mathrm{O}$ reductase is less active at low $\mathrm{pH}$ compared to other enzyme activities in denitrification process (McMillan et al., 2016), which leads to increase of $\mathrm{N}_{2} \mathrm{O}$ emission with increase of acidity in a Japanese Andosol (Mukumbuta et $a l ., 2018)$. Peat soil is acidic due to rich in organic acids, which can increase of $\mathrm{N}_{2} \mathrm{O}$ emission especially in cropland.

$\mathrm{Mu}$ et al. (2014) shows that $\mathrm{N}_{2} \mathrm{O}$ emission increased with the increase of $\mathrm{CO}_{2}$ emission by peat decomposition using the 122 published data of $\mathrm{N}_{2} \mathrm{O}$ and $\mathrm{CO}_{2}$ emissions measured at forests, grasslands and croplands in northern and tropical peatlands. The emission data were obtained by closed chamber methods. However, some of peat decomposition ( $\mathrm{Rh}, \mathrm{kg} \mathrm{Cha}^{-1} \mathrm{y}^{-1}$ ) was estimated from soil respiration (Rt, $\mathrm{kg} \mathrm{Cha}^{-1} \mathrm{y}^{-1}$ ) including root respiration using an empirical equation, $\mathrm{Rh}=10 \exp (0.22+0.87 \ln (\mathrm{Rt} / 10))$, proposed by Bond-Lamberty and Thomson (2010). It was shown that $\mathrm{N}_{2} \mathrm{O}$ emission was significantly correlated with mineral $\mathrm{N}$ input (sum of application rate of nitrogen fertilizer and mineralized nitrogen estimated by dividing $\mathrm{Rh}$ by soil $\mathrm{C} / \mathrm{N}$ ratio), ground water table level, and soil $\mathrm{pH}$. However, data sets from tropical peatlands were only 12 from Malaysia and Indonesia. Therefore, newly published 30 data sets from tropical peatlands were added in this paper (Melling et al., 2007; Takakai et al., 2006; Toma et al., 2011), total
152 data sets including 87 data from unfertilized northern peatland, 23 data from fertilized northern peatland, 26 data from unfertilized tropical peatland and 16 data from fertilized tropical peatland were obtained. In this paper, comparison between tropical peatland and northern boreal and temperate peatland was conducted in terms of the relations between $\mathrm{N}_{2} \mathrm{O}$ and $\mathrm{CO}_{2}$ emissions and the effect of fertilization on the emissions. Statistical analyses were performed with Excel Statistics version 5.0 (Esumi, Tokyo, Japan). The differences in the emissions between fertilization and unfertilization and between tropical peatland and northern boreal and temperate peatland were analyzed with a two-way analysis of variance (ANOVA) and Tukey test.

$\mathrm{CO}_{2}$ emission was significantly higher in tropical peatland than northern boreal and temperate peatland, and increased with $\mathrm{N}$ fertilization significantly $(3815 \pm 2900$ and $4822 \pm 2313 \mathrm{~kg} \mathrm{C} \mathrm{ha}^{-1} \mathrm{y}^{-1}$ in unfertilized and fertilized northern boreal and temperate peatland, respectively, and $7382 \pm 3558$ and $13001 \pm 3027 \mathrm{~kg} \mathrm{Cha}^{-1} \mathrm{y}^{-1}$ in unfertilized and fertilized tropical peatland, respectively) (Fig. 3). $\mathrm{N}_{2} \mathrm{O}$ emission increased with $\mathrm{N}$ fertilization significantly, especially in tropical peatland $(4.93 \pm 10.04$ and $17.76 \pm 21.15$ $\mathrm{kg} \mathrm{N} \mathrm{ha}{ }^{-1} \mathrm{y}^{-1}$ in unfertilized and fertilized northern boreal and temperate peatland, respectively, and $8.08 \pm 15.69$ and $178.59 \pm 218.28 \mathrm{~kg} \mathrm{~N} \mathrm{ha}^{-1} \mathrm{y}^{-1}$ in unfertilized and fertilized tropical peatland, respectively) (Fig. 4). Furthermore, in all peatlands, $\mathrm{CO}_{2}$ and $\mathrm{N}_{2} \mathrm{O}$ emissions increased with the fall of ground water table level, and much larger increase was found in nitrogen fertilized peatlands (Figs 5, 6). Increase of $\mathrm{CO}_{2}$ emission with the fall of water table level was larger in tropical peatland than in northern boreal and temperate peatland, and maximum $\mathrm{CO}_{2}$ emission of $19 \mathrm{Mg} \mathrm{Cha}^{-1} \mathrm{y}^{-1}$ was found at $-80 \mathrm{~cm}$ of water table level (Fig. 5). Increase of $\mathrm{N}_{2} \mathrm{O}$ emission with the fall of water table level was distinct below $-40 \mathrm{~cm}$ of water table level, and especially in tropical peatland, maximum $\mathrm{N}_{2} \mathrm{O}$ emission of $700 \mathrm{~kg} \mathrm{~N}^{-1} \mathrm{y}^{-1}$ was found in -60 to $-70 \mathrm{~cm}$ of water table level (Fig. 6).

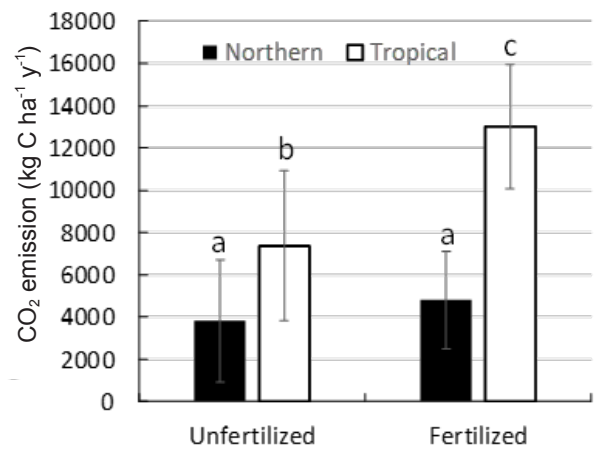

Fig. 3. Comparison of annual $\mathrm{CO}_{2}$ emission with peat decomposition in terms of nitrogen fertilization and climate zone. Error bar reveals standard deviation. Different letters reveals significant difference among the treatments of both fertilization and climate zone (data compiled by $\mathrm{Mu}$ et al., 2014 and combined with those from Melling et al., 2007; Takakai et al., 2006; and Toma et al., 2011). 


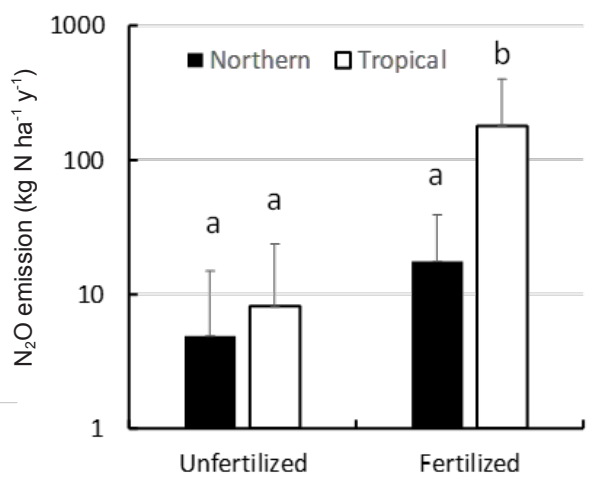

Fig. 4. Comparison of annual $\mathrm{N}_{2} \mathrm{O}$ emission in terms of nitrogen fertilization and climate zone. Error bar reveals standard deviation. Different character reveals significant difference among the treatments of both fertilization and climate zone (data compiled by $\mathrm{Mu}$ et al., 2014 and combined with those from Melling et al., 2007; Takakai et al., 2006 and Toma et al., 2011).

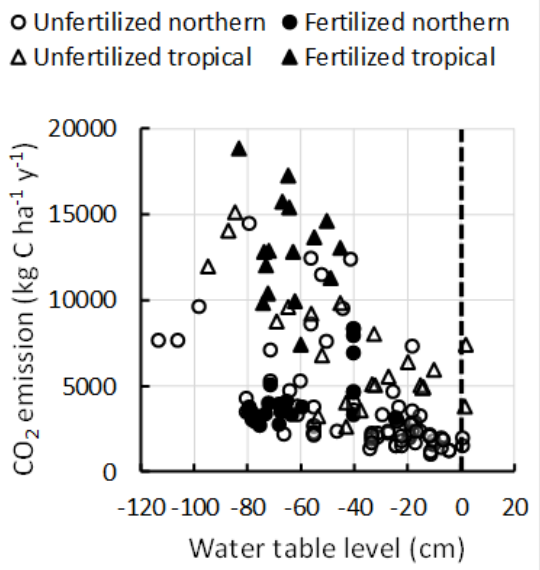

Fig. 5. Relationship between annual $\mathrm{CO}_{2}$ emission and annual mean ground water table level in peatlands (data compiled by $\mathrm{Mu}$ et al., 2014 and combined with those from Melling et al., 2007; Takakai et al., 2006 and Toma et al., 2011).

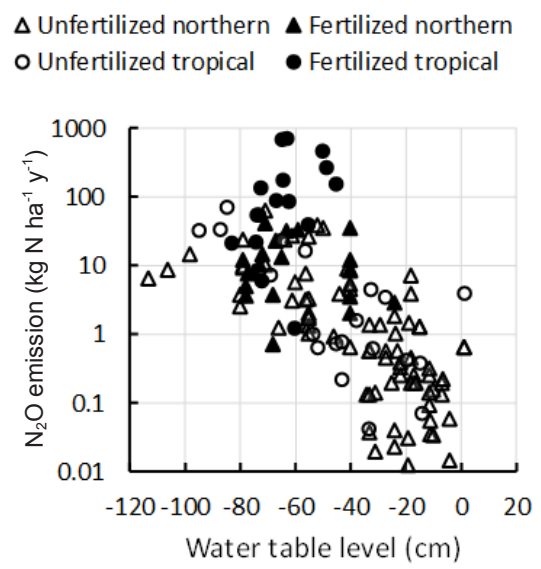

Fig. 6. Relationship between annual $\mathrm{N}_{2} \mathrm{O}$ emission and annual mean ground water table level in peatlands (data compiled by $\mathrm{Mu}$ et al., 2014 and combined with those from Melling et al., 2007; Takakai et al., 2006 and Toma et al., 2011).
There was a significant relationship between mineral nitrogen input and $\mathrm{N}_{2} \mathrm{O}$ emission (Fig. 7). This indicates that increase of peat decomposition with a fall of water table level and $\mathrm{N}$ fertilizer application increases $\mathrm{N}_{2} \mathrm{O}$ emission.

In an upland field of tropical peatland where large $\mathrm{N}_{2} \mathrm{O}$ emission was observed, there was a significant relationship between $\mathrm{NO}_{3}-\mathrm{N}$ content in top soil and $\mathrm{N}_{2} \mathrm{O}$ flux at more than $60 \%$, of WFPS suggesting $\mathrm{N}_{2} \mathrm{O}$ emission was caused by denitrification after mineralization and nitrification (Takakai et al., 2006). Soil microbes which adapted to low $\mathrm{pH}$ of tropical peatland and obtained nitrate respiration ability, fungi (Fusarium oxysporum and Neocosmospora vasinfecta) (Yanai et al., 2007) and bacteria (Janthinobacterium) (Hashidoko et al., 2008), were identified.

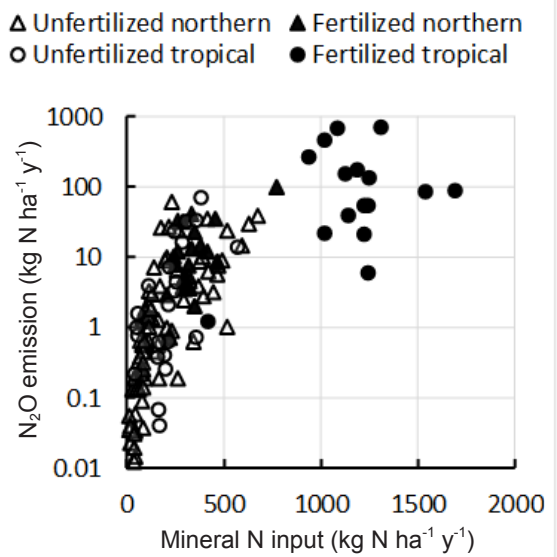

Fig. 7. Relationship between annual $\mathrm{N}_{2} \mathrm{O}$ emission and annual mineral nitrogen input in peatlands (data compiled by $\mathrm{Mu}$ et al., 2014 and combined with those from Melling et al., 2007; Takakai et al., 2006 and Toma et al., 2011).

From the findings above, ground water table level is major controlling factor of $\mathrm{CH}_{4}$ and $\mathrm{N}_{2} \mathrm{O}$ emissions from peatlands. Ground water table level rising above $-20 \mathrm{~cm}$ increases $\mathrm{CH}_{4}$ emission. The increase of $\mathrm{CH}_{4}$ emission is lager in northern boreal and temperate peatland than in tropical peatland due to higher water permeability in tropical peatland. However, loss of natural vegetation with aerial roots and peat subsidence by disturbance especially by fire in tropical peatland increases $\mathrm{CH}_{4}$ emission significantly due to loss of plant mediated oxygen supply and decrease of redox potential under stagnant water on the soil surface. On the other hand, ground water level from -40 to $-70 \mathrm{~cm}$ stimulates $\mathrm{N}_{2} \mathrm{O}$ emission together with $\mathrm{CO}_{2}$ emission. Nitrogen fertilizer application increases $\mathrm{N}_{2} \mathrm{O}$ and $\mathrm{CO}_{2}$ emissions significantly especially in tropical peatland. Overall emission data show the lowest emissions of $\mathrm{CH}_{4}$ and $\mathrm{N}_{2} \mathrm{O}$ are achieved in the range of -20 to $-40 \mathrm{~cm}$ of ground water level. Figure 8 shows the mean and standard deviation of total GWP of $\mathrm{CO}_{2}, \mathrm{~N}_{2} \mathrm{O}$ and $\mathrm{CH}_{4}$ in three ranges of water table level, higher than $-20 \mathrm{~cm}$, from -20 to $-40 \mathrm{~cm}$ and lower than $-40 \mathrm{~cm}$. The GWP $\left(\mathrm{kg} \mathrm{CO}_{2} \mathrm{ha}^{-1} \mathrm{y}^{-1}\right)$ 


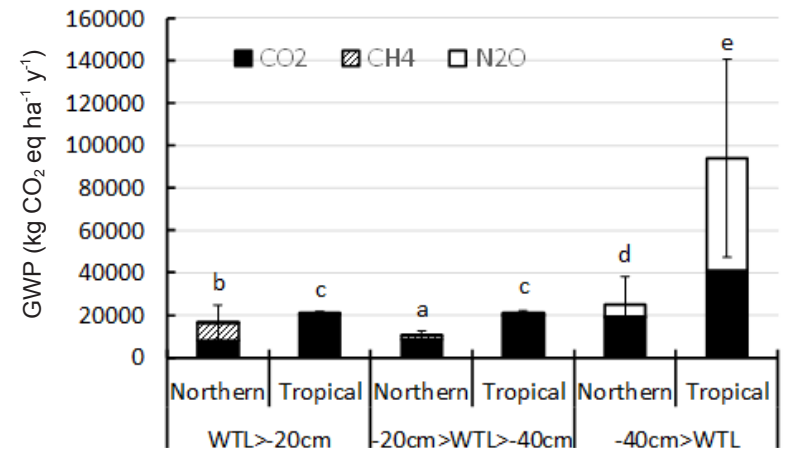

Fig. 8. Comparison of annual global warming potential (GWP) in terms of ground water table level (WTL) and climate zone. Error bar reveals standard deviation of total GWP. Different character reveals significant difference among the treatments of ground water table level and climate zone.

of each gas was obtained from the data of Fig. 1 for $\mathrm{CH}_{4}$ and Fig. 5 for $\mathrm{CO}_{2}$ and Fig. 6 for $\mathrm{N}_{2} \mathrm{O}$, using the factors reported by IPCC 2014, as $\mathrm{GWP}_{\mathrm{CO}_{2}}=\mathrm{CO}_{2}$ emission $(\mathrm{kg}$ $\left.\mathrm{C} \mathrm{ha} \mathrm{y}^{-1}\right) \times 44 / 12, \mathrm{GWP}_{\mathrm{CH}_{4}}=\mathrm{CH}_{4}$ emission $\left(\mathrm{kg} \mathrm{C} \mathrm{ha}^{-1} \mathrm{y}^{-1}\right)$ $\times 16 / 12 \times 28$ and $\mathrm{GWP}_{\mathrm{N}_{2} \mathrm{O}}=\mathrm{N}_{2} \mathrm{O}$ emission $\left(\mathrm{kg} \mathrm{N} \mathrm{ha}^{-1} \mathrm{y}^{-1}\right)$ $\times 44 / 28 \times 265$. Unit of $\mathrm{CH}_{4}$ emission in Fig. 1 was converted to calculate $\mathrm{GWP}_{\mathrm{CH}_{4}}$. Northern boreal and temperate peatland showed the significantly lowest total GWP in the range of water table level from -20 to $-40 \mathrm{~cm}$, and tropical peatland showed that total GWP was significantly lower in the range of water table level from -20 to $-40 \mathrm{~cm}$ than the water table level lower than $-40 \mathrm{~cm}$, and there was no significant difference of total GWP between the ranges of water table level higher than $-20 \mathrm{~cm}$ and from -20 to $-40 \mathrm{~cm}$. However, total GWP was significantly higher in tropical peatland than in northern boreal and temperate peatland. In both tropical and northern boreal and temperate peatlands, contribution of $\mathrm{CO}_{2}$ emission to total GWP was highest in the all ranges of water table level. $\mathrm{CH}_{4}$ emission showed larger contribution in the higher range of water table level, and especially in northern boreal and temperate peatland, contribution of $\mathrm{CH}_{4}$ emission was similar to that of $\mathrm{CO}_{2}$ emission. On the other hand, contribution of $\mathrm{N}_{2} \mathrm{O}$ emission was higher in the lower range of water table level, and especially in tropical peatland, contribution of $\mathrm{N}_{2} \mathrm{O}$ emission was similar to that of $\mathrm{CO}_{2}$ emission.

\section{SUMMARY}

Water table level from $-20 \mathrm{~cm}$ to $-40 \mathrm{~cm}$ was optimal to minimize $\mathrm{CH}_{4}, \mathrm{CO}_{2}$ and $\mathrm{N}_{2} \mathrm{O}$ emissions in peatlands. Tropical peatland was lower in $\mathrm{CH}_{4}$ emission than northern boreal and temperate peatland, however, stagnant surface water in subsided and fired tropical peatland induced high $\mathrm{CH}_{4}$ flux. On the other hand, tropical peatland was higher in $\mathrm{N}_{2} \mathrm{O}$ emission than northern boreal and temperate peatland. Falling ground water table level stimulated organic matter decomposition significantly, leading to increase of minera- lized $\mathrm{N}$ resulting in increase of $\mathrm{N}_{2} \mathrm{O}$ emission. Application of nitrogen fertilizer especially in tropical peatland increases $\mathrm{N}_{2} \mathrm{O}$ emission significantly due to significant increase of organic matter decomposition.

Conflict of interest: The Authors do not declare conflict of interest.

\section{REFERENCES}

Adji F.F., Hamada Y., Darang U., Limin S.H., and Hatano R., 2014. Effect of plant-mediated oxygen supply and drainage on greenhouse gas emission from a tropical peatland in Central Kalimantan, Indonesia. Soil Sci. Plant Nutrition, 60, 216-230. https://doi.org/10.1080/00380768.2013.872019

Bond-Lamberty B., and Thomson A., 2010. A global database of soil respiration data. Biogeosciences, 7, 1915-1926. https://doi.org/10.5194/bg-7-1915-2010

Couwenberg J., Dommain R., and Joosten H., 2010. Greenhouse gas fluxes from tropical peatlands in south-east Asia. Global Change Biol., 16, 1715-1732. https://doi. org/10.1111/j.1365-2486.2009.02016.x

Desyatkin A.R., Takakai F., and Hatano R., 2014. Flood effect on $\mathrm{CH}_{4}$ emission from the alas in Central Yakutia, East Siberia. Soil Sci. Plant Nutrition, 60, 242-253. https://doi. org/10.1080/00380768.2014.883486

Furukawa Y., Inubushi K., Ali M., Itang A.M., and Tsuruta H., 2005. Effect of changing groundwater levels caused by land-use changes on greenhouse gas fluxes from tropical peat lands. Nutrient Cycling in Agroecosystems, 71, 81-91. https://doi.org/10.1007/s10705-004-5286-5

Hadi A., Inubushi K., Furukawa Y., Purnomo E., Rasmadi M., and Tsuruta H., 2005. Greenhouse gas emissions from tropical peatlands of Kalimantan, Indonesia. Nutrient Cycling in Agroecosystems, 71, 73-80. https://doi. org/10.1007/s10705-004-0380-2

Hashidoko Y., Takakai F., Toma Y., Darung U., Melling L., Tahara S., and Hatano R., 2008. Emergence and behaviors of acid-tolerant Janthinobacterium sp. that evolves $\mathrm{N}_{2} \mathrm{O}$ from deforested tropical peatland. Soil Biol. Biochemistry, 40, 116-125. https://doi.org/10.1016/j. soilbio.2007.07.014

IPCC, 2013. Climate Change 2013: The Physical Science Basis. Contribution of Working Group I to the Fifth Assessment Report of the Intergovernmental Panel on Climate Change (Eds T.F. Stocker, D. Qin, G.-K. Plattner, M. Tignor, S.K. Allen, J. Boschung, A. Nauels, Y. Xia, V. Bex and P.M. Midgley). Cambridge University Press, Cambridge, United Kingdom and New York, NY, USA. https://doi.org/10.1017/ cbo9781107415324.023

IPCC, 2014. Climate Change 2014: Synthesis Report. Contribution of Working Groups I, II and III to the Fifth Assessment Report of the Intergovernmental Panel on Climate Change (Core Writing Team, Eds R.K. Pachauri and L.A. Meyer). IPCC, Geneva, Switzerland. https://doi.org/10.1017/ cbo9781107415416

Ishikura K., Darung U., Inoue T., and Hatano R., 2018. Variation in soil properties regulate greenhouse gas fluxes 
and global warming potential in three land use types on tropical peat. Atmosphere, 9, 465. https://doi.org/10.3390/ atmos9120465

Ishikura K., Yamada H., Toma Y., Takakai F., Morishita T., Darung U., Limin A., Limin S.H., and Hatano R., 2017. Effect of groundwater level fluctuation on soil respiration rate of tropical peatland in Central Kalimantan, Indonesia. Soil Sci. Plant Nutrition, 63, 1-13. https://doi.org/10.1080/0 0380768.2016.1244652

Jauhiainen J., Limin S., Silvennoinen H., and Vasander H., 2008. Carbon dioxide and methane fluxes in drained tropical peat before and after hydrological restoration. Ecology, 89, 3503-3514. https://doi.org/10.1890/07-2038.1

Kelly T.J., Baird A.J., Roucoux K.H., Baker T.R., Honorio C.E.N., Lawson I.T., and Ríos M., 2014. The high hydraulic conductivity of three wooded tropical peat swamps in northeast Peru: Measurements and implications for hydrological function. Hydrological Processes, 28, 3373-3387. https://doi.org/10.1002/hyp.9884

Kolb S. and Horn M.A., 2012. Microbial $\mathrm{CH}_{4}$ and $\mathrm{N}_{2} \mathrm{O}$ consumption in acidic wetlands. Frontiers in Microbiology, 3, 1-8. https://doi.org/10.3389/fmicb.2012.00078

Linn D.M. and Doran J.W., 1984. Effect of water-filled pore space on carbon dioxide and nitrous oxide production in tilled and nontilled soils. Soil Sci. Soc. Am. J., 48, 1267-1272. https://doi.org/10.2136/sssaj1984.03615995004800060013x

Lloyd J. and Taylor J.A., 1994. On the temperature-dependence of soil respiration. Functional Ecology, 8, 315-323.

McMillan A.M.S., Pal P., Phillips R.L., Palmada T., Berben P.H., Jha N., Saggar S., Luo J., 2016. Can pH amendments in grazed pastures help reduce $\mathrm{N}_{2} \mathrm{O}$ emissions from denitrification? - The effects of liming and urine addition on the completion of denitrification in fluvial and volcanic soils. Soil Biology and Biochemistry, 93, 90-104. https:// doi.org/10.1016/j.soilbio.2015.10.013

Melling L., 2016. Peatland in Malaysia. Tropical Peatland Ecosystems, 59-73. https://doi.org/10.1007/978-4-43155681-7_4

Melling L., Hatano R., and Goh K.J., 2005. Soil respiration from three ecosystems in tropical peatland of Sarawak, Malaysia. Tellus, 57, 1-11. https://doi.org/10.1111/j.16000889.2005.00129.x

Melling L., Hatano R., and Goh K.J., 2007. Nitrous oxide emissions from three ecosystems in tropical peatland of Sarawak, Malaysia. Soil Sci. Plant Nutrition, 53: 792-805. https://doi. org/10.1111/j.1747-0765.2007.00196.x

Mu Z.. Huang A., Kimura S.D., Jin T., Wei S., and Hatano R., 2009. Linking $\mathrm{N}_{2} \mathrm{O}$ emission to soil mineral $\mathrm{N}$ as estimated by $\mathrm{CO}_{2}$ emission and soil $\mathrm{C} / \mathrm{N}$ ratio. Soil Biol. Biochem., 41, 2593-2597. https://doi.org/10.1016/j.soilbio.2009.09.013

Mu Z., Huang A., Ni J., and Xie D., 2014. Linking annual $\mathrm{N}_{2} \mathrm{O}$ emission in organic soils to mineral nitrogen input as estimated by heterotrophic respiration and soil $\mathrm{C} / \mathrm{N}$ ratio. Plos One, 9, e96572. https://doi.org/10.1371/journal.pone. 0096572

Mukumbuta I., Uchida Y., and Hatano R., 2018. Evaluating the effect of liming on $\mathrm{N}_{2} \mathrm{O}$ fluxes from denitrification in an
Andosol using the acetylene inhibition and N-15 isotope tracer methods. Biol. Fertility Soils, 54, 71-81. https://doi. org/10.1007/s00374-017-1239-4

Page S.E. and Baird A.J., 2016. Peatlands and global change: response and resilience. Annual Review of Environment and Resources, 41, 35-57. https://doi.org/10.1146/annurevenviron-110615-085520

Pangala S.R., Moore S., Hornibrook E.R., Gauci V., 2013. Trees are major conduits for methane egress from tropical forested wetlands. New Phytologist, 197, 524-31. https:// doi.org/10.1111/nph.12031

Repo M.E., Susiluoto S., Lind S.E., Jokinen S., Elsakov V., Biasi C., Virtanen T., and Martikainen P.J., 2009. Large $\mathrm{N}_{2} \mathrm{O}$ emissions from cryoturbated peat soil in tundra. Nature Geoscience, 2, 189-192. https://doi.org/10.1038/ngeo434

Saggar S., Jha N., Deslippe J., Bolan N.S., Luo J., Giltrap D.L., Kim D.G., Zaman M., and Tillman R.W., 2013. Denitrification and $\mathrm{N}_{2} \mathrm{O}: \mathrm{N}_{2}$ production in temperate grasslands: Processes, measurements, modelling and mitigating negative impacts. Sci. Total Environ., 465, 173-195. https:// doi.org/10.1016/j.scitotenv.2012.11.050

Schütz H., Seiler W., and Conrad R., 1989. Processes involved in formation and emission of methane in rice paddies. Biogeochemistry, 7, 33-53. https://doi.org/10.1007/bf00000896

Šimek M., Jíšová L., and Hopkins D.W., 2002. What is the so-called optimum $\mathrm{pH}$ for denitrification in soil? Soil Biol. Biochem., 34,1227-1234. https://doi.org/10.1016/s00380717(02)00059-7

Spahni R., Wania R., Neef L., van Weele M., Pison I., Bousquet P., Frankenberg C., Foster P.N., Joos F., Prentice I.C., and van Velthoven P., 2011. Constraining global methane emissions and uptake by ecosystems, Biogeosciences, 8, 1643-1665. https://doi.org/10.5194/bg-8-1643-2011

Takahashi H., 1999. Hydrological and meteorological environments of inland peat swamp forest in central Kalimantan, Indonesia with special reference to the effects of forest fire. Tropics, 9(1), 17-25. https://doi.org/10.3759/tropics.9.17

Takakai F., Morishita T., Hashidoko Y., Darung U., Kuramochi K., Dohong S., Limin S.H., and Hatano R., 2006. Effects of agricultural land-use change and forest fire on $\mathrm{N}_{2} \mathrm{O}$ emission from tropical peatlands, Central Kalimantan, Indonesia. Soil Sci. Plant Nutrition, 52, 662-674. https://doi. org/10.1111/j.1747-0765.2006.00084.x

Takai Y., 1970. The mechanism of methane fermentation in flooded paddy soil. Soil Sci. Plant Nutrition, 16, 238-244. https:// doi.org/10.1080/00380768.1970.10433371

Toma Y., Takakai F., Darung U., Kuramochi K., Limin S.H., Dohong S., and Hatano R., 2011. Nitrous oxide emission derived from soil organic matter decomposition from tropical agricultural peat soil in central Kalimantan, Indonesia. Soil Sci. Plant Nutrition, 57, 436-451. https://doi.org/10.10 80/00380768.2011.587203

UNEP, 2013. Drawing Down $\mathrm{N}_{2} \mathrm{O}$ To Protect Climate and the Ozone Layer. United Nations Environment Programme (UNEP), Nairobi, Kenya.

van der Werf G.R., Morton D.C. DeFries R.S. Olivier J.G.J., Kasibhatla P.S., Jackson R.B., Collatz G.J. and 
Randerson J.T., 2009. $\mathrm{CO}_{2}$ emissions from forest loss. Nature Geoscience, 2, 737-738. https://doi.org/10.1038/ ngeo671

Yanai Y., Toyota K., Morishita T., Takakai F., Hatano R., Limin S.H.., Darung U., and Dohong S., 2007. Fungal $\mathrm{N}_{2} \mathrm{O}$ production in an arable peat soil in Central Kalimantan, Indonesia. Soil Sci. Plant Nutrition, 53, 806-811. https:// doi.org/10.1111/j.1747-0765.2007.00201.x

Yu Z., Loise J., Brosseau D.P., Beilman D.W. and Hunt S.J.,
2010. Global peatland dynamics since the Last Glacial Maximum. Geophysical Res. Letters, 37, L13402. https:// doi.org/10.1029/2010gl043584

Zhou L., Zhou X., Zhang B., Lui M., Luo Y., Liu L., and Li B., 2014. Different responses of soil respiration and its components to nitrogen addition among biomes: A meta-analysis. Global Change Biol., 20, 2332-2343. https://doi. org/10.1111/gcb. 12490 